Hagar migmatite sheet, the contact with the high-grade metasediments is a thrust zone.

On both sides of Nordenskiöld Gletscher a gently inclined eastward dipping fault or thrust separates the 'Petermann Series' from a group of highly sheared, often mylonitic siliceous rocks. Further west, below the thrust, low-grade micaceous quartzites and semipelitic metasediments are common, and in some places seem to rest on a gneissic basement of regularly banded granitic gneiss with thin amphibolites. There is at present no indisputable evidence of their age. The same is true for the 'Eleonore $\$ \varnothing$ Series' the various units of which were sampled in Arnold Escher Land; these low grade supracrustal rocks seem to occur beneath a thrust in a structural window.

The former assumption that all metasedimentary sequences are equivalents of the Eleonore Bay Group is now suspect. It seems probable that several lithologically similar sedimentary sequences of widely different ages may have been brought into conjuction by Precambrian as well as Caledonian orogenic events. Isotopic studies in progress (Rex et al., this report) support a radically revised interpretation of the whole crystalline complex, but specific correlations of the metasedimentary units are premature without considerably more data.

\title{
References
}

Haller, J. 1953: Geologie und Petrographie von West-Andrées Land und Ost-Frænkels Land (NE-Grönland). Meddr Grønland 113, 5, 196 pp.

Haller, J. 1958: Der "Zentrale Metamorphe Komplex" von NE-Grönland, Teil II. Die geologische Karte der Staunings Alper und des Forsblads Fjordes. Meddr Grønland 154,3, 153 pp.

Haller, J. 1971: Geology of the East Greenland Caledonides. New York: Interscience Publishers, 413 pp.

Henriksen, N. \& Higgins, A. K. 1976: East Greenland Caledonian fold belt. In Escher. A. \& Watt, W. S. (edit.) Geology of Greenland, 182-246. Copenhagen: Geol. Surv. Greenland.

Koch, L. \& Haller, J. 1971: Geological map of East Greenland $72^{\circ}-76^{\circ}$ N. Lat. (1:250 000) Meddr Grønland 183, 26 pp.

Wegmann, C. E. 1935: Preliminary report on the Caledonian orogeny in Christian X's Land (North-East Greenland). Meddr Grønland 103,3, 59 pp.

Wenk, E. \& Haller, J. 1953: Geological explorations in the Petermann region, western part of Frænkels Land, East Greenland. Meddr Grønland 111,3, 48 pp.

\section{Investigations on the Lower Eleonore Bay Group in the Alpefjord region, central East Greenland}

\author{
Renaud Caby
}

The Lower Eleonore Bay Group outcropping on the eastern flank of the 'central metamorphic complex' and in the Alpefjord region comprises a sedimentary sequence more 
than $8000 \mathrm{~m}$ thick. It is overlain concordantly by the Upper Eleonore Bay Group, Tillite Group (Eocambrian) and Cambro-Ordovician sediments.

The Lower Eleonore Bay Group has classically been considered as a geosynclinal sequence, the lower part of which was distinguished by Fränkl $(1951,1953)$ as the Alpefjord Series and divided into groups of beds numbered ' $a$ ' to ' $q$ '. Present division of the sequence into the Lower Arenaceous-Argillaceous Series, Calc-Argillaceous Series and Upper Argillaceous-Arenaceous Series incorporates investigations by B. Evans in the Alpefjord region (Haller \& Kulp, 1962; Haller, 1971).

The main purpose of the current investigations was to carry out sedimentological and stratigraphical studies in the Lower Eleonore Bay Group of the Alpefjord region; and to re-examine the transition zone between the Lower Eleonore Bay Group and the 'central metamorphic complex' (Haller, 1958) especially in view of recent speculations questioning the validity of the classical interpretations of the 'central metamorphic complex' (Wegmann, 1935; Haller, 1971; Friderichsen \& Higgins, this report, and fig. 32).

\section{Stratigraphy and depositional environments}

Detailed investigations were made mainly on the west side of Alpefjord and will be presented in a future account. Here only a few general remarks are given.

Orthoquartzites are very common in the entire succession in units from a few metres to 500 $\mathrm{m}$ thick. Always fine grained, they are mostly thick bedded in the lower part with well developed cross-bedding of typical fluvial type with steeply inclined foreset laminae; in some cases overturned laminae are outlined by heavy minerals. Channel features and large amplitude ripples also occur. In the upper part the orthoquartzites are mostly cemented by diffuse carbonates.

Dark psammitic silty quartzites occur in homogenous thick units (' $\mathrm{f}$ ' of Fränkl, 1951); and are generally rich in large-scale festoon cross-bedding. Remnants of steep channels are also preserved.

Banded quartzite-shale units build up more than 50 per cent of the whole succession. All sedimentary features are of shallow water type and include alternations of different types of ripple marks, longitudinal cross-bedding, climbing ripple laminations, flaser bedding and lenticular bedding (Reineck \& Singh, 1973). Shaly layers are rich in mud cracks and small-scale channels, both types are filled up by sandy material, and similar to those recorded in Canning Land (Caby, 1972). These small-scale channels, which occur throughout the Lower Eleonore Bay Group, resemble on bedding surfaces branching and meandering rill marks with accumulation tongues formed in tidal flats (Reineck \& Singh, 1973, figs 91-94).

Black shales form thick units and are mostly banded on a fine scale. Numerous small-scale channels are present, and mud cracks are developed repeatedly in many units. Carbonatebearing layers, and more frequently brown weathered carbonate-bearing lenses occur in all black shale units.

Green silty varved units, formed by extremely thin, yellow-green and dark green silty laminations frequently with disseminated pyrite and chalcopyrite, occur in lower and upper parts of the succession. They may have been formed as floculated clays under lacustrine conditions (Reineck \& Singh, 1973, fig. 309b). 
The Calc-Argillaceous Series forms a $200 \mathrm{~m}$ unit which was examined in the mountains west of Alpefjord. It comprises pyritic shales, calcarenites, micritic limestones and silty dolomites. Giant polygonal mud cracks up to $4 \mathrm{~cm}$ wide and $1 \mathrm{~m}$ deep and filled by calcite were observed in limy shale layers.

It is concluded that the entire Eleonore Bay Group succession is made up of very shallow water deposits, probably entirely deposited on a subsiding and fluctuating wide deltaic zone from a major river carrying only sand, silt and clay. The general conditions were complex overlapping fluvial, tidal, deltaic, evaporitic and lacustrine environments. A few clay-silt deposits may have been deposited offshore. Eastward current directions predominate in fluvial units of the Lower Arenaceous-Argillaceous Series, and north-east to northward directions are frequent at higher levels.

It is stressed that there is no evidence in the succession examined in support of an interpretation of flysch or greywacke sedimentation of geosynclinal type. Higher levels of the Eleonore Bay Group examined in Canning Land (Bertrand-Sarfati \& Caby, in press) represent very shallow marine deposits. It is clear that the generally adopted concept of a geosynclinal type sequence in the East Greenland Caledonides must be abandoned.

\section{Metamorphism}

In the writer's opinion there is in the region of Alpefjord and Forsblads Fjord a clear transition between non-metamorphosed sediments of the Lower Eleonore Bay Group, through hornfelses and schists into pelitic gneisses and migmatites of the 'central metamorphic complex'; the high grade metasediments are strikingly similar to the Krummedal supracrustal sequence of the northern Scoresby Sund region. The sillimanite grade migmatitic rocks in the inner part of Forsblads Fjord contain scattered, boudinaged and rotated blocks of metasedimentary rocks, mainly quartzites, and often with zoned calc-silicate/carbonate lenses. Fluviatile quartzites, semipelitic units with ripple marks, and heavy mineral bands, exhibiting striking similarities with similar features in the Lower Eleonore Bay Group, have all been observed in high-grade non-migmatitic rocks.

The field observations on which these conclusions are based will be given in detail in a subsequent report, but they agree very well with Haller's (1958) interpretation, and on a regional scale support the traditional views of Caledonian orogenesis put forward by Wegmann (1935), Haller (1971) and others.

They are in disagreement with current viewpoints which depend heavily on isotopic dating for their interpretations (Steiger \& Henriksen, 1972; Phillips et al., 1973; Higgins, 1974; Hansen et al., 1974; Friderichsen \& Higgins, this report). Rejecting in no way the validity of modern geochronology, the author wishes to emphasise that many isotopic problems remain to be solved, especially the possibility of detrital-parental retention ages (or mixed ages) in high-grade rocks (Pidgeon \& Johnson, 1974; Lancelot, 1975, p. 80).

\section{Structure}

The Alpefjord region is a spectacular example of the disharmonious or 'stockwerk' folding between superstructure and infrastructure long ago synthesised for the whole Caledonian fold belt of East Greenland by Wegmann (1935) and Haller (1958). 
In most of the region formed from non-metamorphosed rocks or hornfelses the structure is that of a tilted block, a very simple monocline with beds dipping $30^{\circ}$ to $40^{\circ}$ north-east against the north-east part of the Stauning Alper horst.(Haller, 1958). Fracture cleavage, slaty cleavage and boudinage are developed in certain levels. The minor structures are entirely tensional and not compressive. They indicate an eastwards gliding east of the 'central metamorphic complex', which can be compared to the westwards sense of displacement demonstrated in Canning Land (Caby, 1972, 1976).

A major structure, the Schaffhauserdalen recumbent anticline, forms the eastern margin of the metamorphic complex, occurring above a large-scale detachment zone developed within and below the inverted limb of the fold. This major anticline has a subhorizontal axial surface and can be traced for more than $12 \mathrm{~km}$. The detachment zone marks a transition from ' $a$ ' tectonites seen in the lower part of the superstructure into complex, polyphase, highgrade ' $b$ ' tectonites in the infrastructure.

In sillimanite grade rocks north-south folds seem to be superimposed on earlier isoclinal folds. However, similarities in fabric of all small-scale folds, with co-axial fresh sillimanite and biotite, support the evidence of synchronous refolding at high temperatures giving way to contorted fold axes and curved axial surfaces without preferred geometry presented by Chadwick (1971).

In the migmatite zone, disharmonious contorted flow folds occur, the shape of which seems to be controlled more by diapiric forces than by regional stress. They are associated with the emplacement of migmatites and granites in the infrastructure.

At a higher level marginal intrusive granites occur as sheets 'floating' above the migmatites and gneisses. It is one of these marginal granites, cutting Lower Eleonore Bay Group rocks on the south side of Forsblads Fjord, which has given a Caledonian isochron age of 455 m.y. (Rex et al., this report).

\section{References}

Bertrand-Sarfati, J. \& Caby, R. in press: Carbonates et stromatolites du sommet du Groupe d'Eleonore Bay (Précambrien terminal au Canning Land (Groenland oriental). Bull. Grønlands geol. Unders. 119.

Caby, R. 1972: Preliminary results of mapping in the Caledonian rocks of Canning Land and Wegener Halvø, East Greenland. Rapp. Grønlands geol. Unders. 48, $21-37$.

Caby, R. 1976: Tension structures related to gliding tectonics in the Caledonian superstructure of Canning Land and Wegener Halvø, central East Greenland. Rapp. Grønlands geol. Unders. 72, 24 pp.

Chadwick, B. 1971: Preliminary account of the geology of south-east Renland, Scoresby Sund, East Greenland. Rapp. Grønlands geol. Unders. 34, 32 pp.

Fränkl, E. 1951: Die Untere Eleonore Bay Formation im Alpefjord. Meddr Grønland 151,6, 15 pp.

Fränkl, E. 1953: Die geologische Karte von Nord-Scoresby Land (NE-Grønland). Meddr Grønland $113,6,56 \mathrm{pp}$.

Haller, J. 1958: Der "Zentrale Metamorphe Komplex" von NE-Grönland, Teil II. Die geologische Karte der Staunings Alper und des Forsblads Fjordes. Meddr Grønland 154,3, 153 pp.

Haller, J. 1971: Geology of the East Greenland Caledonides. New York: Interscience Publishers, 413 pp.

Haller, J. \& Kulp, J. L. 1962: Absolute age determinations in East Greenland. Meddr Grønland 171,1, 77 pp. 
Lancelot, J. R. 1975: Les systèmes uranium-plomb chronomètres et traceurs de l'évolution des roches terrestres. Thesis I.P.G., Paris, 280 pp.

Phillips, W. E. A., Stillman, C. J., Friderichsen, J. D. \& Jemelin, L. 1973: Preliminary results of mapping in the western gneiss and schist zone around Vestfjord and inner Gåsefjord, south-west Scoresby Sund. Rapp. Grønlands geol. Unders. 58, 17-32.

Pidgeon, R. T. \& Johnson, M. R. W. 1974: A comparison of zircon U-Pb and whole rock Rb-Sr systems in three phases of the Carn Chuinneag granite, northern Scotland, Earth Planet, Sci. Lett. 24, 105-112.

Reineck, H. E. \& Singh, I. B. 1973: Depositional sedimentary environments. New York: Springer Verlag, 439 pp.

Steiger, R. H. \& Henriksen, N. 1972: The geochronology of the Scoresby Sund area. Progress report 3: zircon ages. Rapp. Grønlands geol: Unders. 48, 109-114.

Wegmann, E. 1935: Zur Deutung der Migmatite, Geol. Rdsch. 26, 305-350.

Centre Geophysique et Geologique, Université des Sciences Montpellier,

9 Rue Pouget, Montpellier, 34000 France.

\section{Sedimentological observations in middle and late Triassic rocks, Jameson Land Basin, central East Greenland}

\section{Lars B. Clemmensen and Frank Andreasen}

The middle and late Triassic rocks of Jameson Land and the nearby part of the Scoresby Land area in central East Greenland (fig. 33) were studied during the 1975 field season as part of a $21 / 2$-year joint GGU-University of Copenhagen project. The work entailed the detailed measurement of several sedimentological sections. Emphasis was laid on the primary sedimentary structures and a large number of palaeocurrent measurements were carried out. The ultimate goal of this approach is to understand the palaeogeographical evolution of the sedimentary basin during middle and late Triassic time.

This note is a preliminary account and delineates only the sedimentary history of the basin in very broad terms.

\section{Stratigraphy}

The studied sedimentary sequence belongs to the middle and late Triassic Gipsdalen and Fleming Fjord Formations (Perch-Nielsen et al., 1972, 1974) and to the overlying Kap Stewart Formation of Rhaetic-Liassic age (Surlyk et al., 1973). The Gipsdalen Formation consists of the basal Solfaldsdal Member and the overlying Kap Seaforth Member; the Fleming Fjord Formation is composed from base upwards of the Edderfugledal Member, the 